\title{
Effects of Covid-19 on the Economy of An Oil Dependent Nigeria
}

\author{
Adesuyi John Olumuyiwa (Ph.D) ${ }^{1} \quad$ Suleiman Musa Ibrahim (Msc) ${ }^{2}$ \\ 1.Ph.D in Business, Law and Social science, University of Abertay Dundee Business School, Scotland, United \\ Kingdom \\ 2.International Energy Studies and Energy Economics, University of Dundee, Scotland, UnitedKingdom
}

\begin{abstract}
The Coronavirus (COVID - 19) has created anxiety and fear, it has hit the global economy, and has amplified volatility in several international and domestic financial markets. It is a deadly virus that forced the world into a near total lock down and it has claimed millions of lives round the world. The oil price reaction to COVID -19 was stable and accommodating up until March $22^{\text {nd }}, 2020$ after the release of the first coronavirus monitoring report by the World Health Organization (WHO). Not long after Saudi Arabia floods the market with oil, as a result, international prices drop with more than $20 \%$ in one single day. Against this background, the purpose of this paper is to investigate the impact of COVID - 19 figures on crude oil prices. The pandemic has negatively influenced on education, economy, religious worship, sporting activities, social gatherings, banking activities, and others. The state governments, military, NGO, federal government, individuals, and religious bodies provided and donated palliatives to cushion the effects of the pandemic on the populace.
\end{abstract}

Keywords: Covid-19, Financial Volatility, Coronavirus, Oil Price, Global Economy, World Health Organization DOI: $10.7176 / \mathrm{JETP} / 11-1-02$

Publication date: January $31^{\text {st }} 2021$

\section{Introduction}

Coronavirus disease 2019 (COVID-19) is an infectious disease caused by severe acute respiratory syndrome coronavirus 2 (SARS-CoV-2). The disease was first identified in December 2019 in Wuhan, the capital of China's Hubei province, and has since spread globally, resulting in the ongoing 2019/20 coronavirus pandemic. Common symptoms include fever, cough and shortness of breath (Chauhan, 2020). The World Health Organization (WHO) declared the 2019/20 coronavirus outbreak, a Public Health Emergency of International Concern (PHEIC) on 30 January 2020 and a pandemic on 11 March 2020. Local transmission of the disease has been recorded in many countries across all six WHO regions (W.H.O, 2020).

COVID-19 has already developed into a pandemic, with small chains of transmission in many countries and large chains resulting in extensive spread in a few countries, such as Italy, Iran, South Korea, and Japan. It is already evident Governments will not be able to minimise both deaths from coronavirus disease 2019 (COVID19) and the economic impact of viral spread. Keeping mortality as low as possible will be the highest priority for individuals; hence governments around the world put in place measures to ameliorate the inevitable economic downturn. Most countries-initiated quarantine, social distancing, and isolation of infected populations in order to contain the epidemic (Anderson et al, 2020).

In the last few months, the entire world has experienced a surprising turn of events which has brought about a collapse of different sectors globally. The corona pandemic has brought a collapse in the oil industry as the world has seen a consistent and volatile period in the price of oil in more than 17 years at -USD \$39 per barrel (IEA, 2020).

In this framework, the present research attempts to investigate how the COVID -19 infection cases affect the oil price, OPEC, and Nigeria. The price war between Saudi Arabia and Russia has been a huge catalyst to the oil collapse as well, the two had previously co-operated on crude output but fell out over Riyadh's calls for greater production cuts to boost the price.

\section{Crude Oil Price Volatility}

Brent crude, the international benchmark, lost up to $13 \%$ in 2020 to hit a low of $\$ 24.72$ a barrel, a level last seen in 2003. US benchmark, West Texas Intermediate, fell even more, losing $23 \%$ to hit a low of $\$ 20.48$ a barrel (Financial times, 2020). The International Energy Agency (IEA) has already warned of the economic hit to poorer producers such as Iraq and Ecuador, saying that their revenues from oil and gas sales could fall as much as 85 per cent this year. For countries dependent on energy sales to fund government budgets, a collapse in revenue could undermine health systems set to be tested by the coronavirus's spread (IEA \& Financial times, 2020).

Despite the pain of plunging oil prices, neither Russia nor Saudi Arabia seemed ready to back down on their plan to boost production and flood the market. Nevertheless, Russia is on record indicated as portrayed by the Financial times it would prefer higher oil prices, as it revealed that the recent crash meant it would run a budget deficit this year but gave little indication of it plans to pull back from its confrontation with Saudi Arabia in the oil market (Financial times, 2020). Many oil analysts believe Saudi Arabia is trying to push Russia back to the 
negotiating table. But the extent of the collapse in oil demand now forecast with entire European countries locking down and major US cities imposing restrictions may make it difficult for the two energy giants to formulate an effective response, even if they were on better terms. This issue was at its most intense May 2020, WTI showcased that oil demand was at its weakest, partly since full coronavirus containment measures in place across much of the US. Storage at the Oklahoma facility became full within weeks. As of $10^{\text {th }}$ April 2020, Cushing's tanks housed 55 million barrels of crude, or $72 \%$ of working storage capacity of 76.1 million barrels (Financial Times, 2020).

It was noted that Russia's readiness to offer steep discounts for its oil was designed to bankrupt U.S. shale. This led to Saudi Arabia accusing Russia of breaking up the OPEC+ coalition agreement (World Oil, 2020). However, a new OPEC + deal was reached, the new OPEC+ deal put the Saudi-Russia feud behind and was an effort to respond to the glut threatening to fill up global storage within weeks as demand crashed amid the COVID19 pandemic. The nearly 10 million bpd cut would be for just two months May and June 2020 after which the producers will soften the cuts (Oil price, 2020).

To mitigate their storage crises Crude Oil Importing Countries (Crude Oil Buyers) urged deeper production cuts from OPEC; and placed further tariffs on foreign oil imports; freeing up more storage capacity, including National Strategic Petroleum Reserves (SPR). A major strategy deployed was paying producers to keep oil in the ground; or extending financial support to oil companies (Financial Times, 2020).

The recent intervention by the Organization of Petroleum Exporting Countries (OPEC) and its allies, led by Russian, to cut global crude oil will not impact the market immediately, market analysts say the record output cuts by OPEC $+\left(\right.$ expected to take effect from May $\left.1^{\text {st }}, 2020\right)$ needs some time to rebalance the market (Premium Times, 2020).

\section{Negative Crude Oil Price}

The 2020 May WTI contract briefly touched USD \$40/bbl. intraday. The severe drop on was driven in part by a technicality of the global oil market. Oil is traded on its future price and May futures contracts are due to expire on Tuesday. Traders were keen to offload those holdings to avoid having to take delivery of the oil and incur storage costs.

It is probably the first time in history that a negative price formed in the futures market (Electricity and natural gas have been traded at negative prices in spot markets in various locations). Although unprecedented, the actual significance of this move is smaller than the headline news may suggest. On expiry of the 2020 May WTI contract, it's normal that the futures prices are volatile during the last few days of trading. Yet the negative price is unprecedented and largely due to the fear of running out of storage capacity in Cushing (the delivery point of WTI). The June WTI contract and the Brent also dropped around 10\%, but less than history-making.

This means oil producers are paying buyers to take the commodity off their hands over fears that storage capacity could run out in May. As a result, oil firms have resorted to renting tankers to store the surplus supply and that has forced the price of US oil into negative territory.

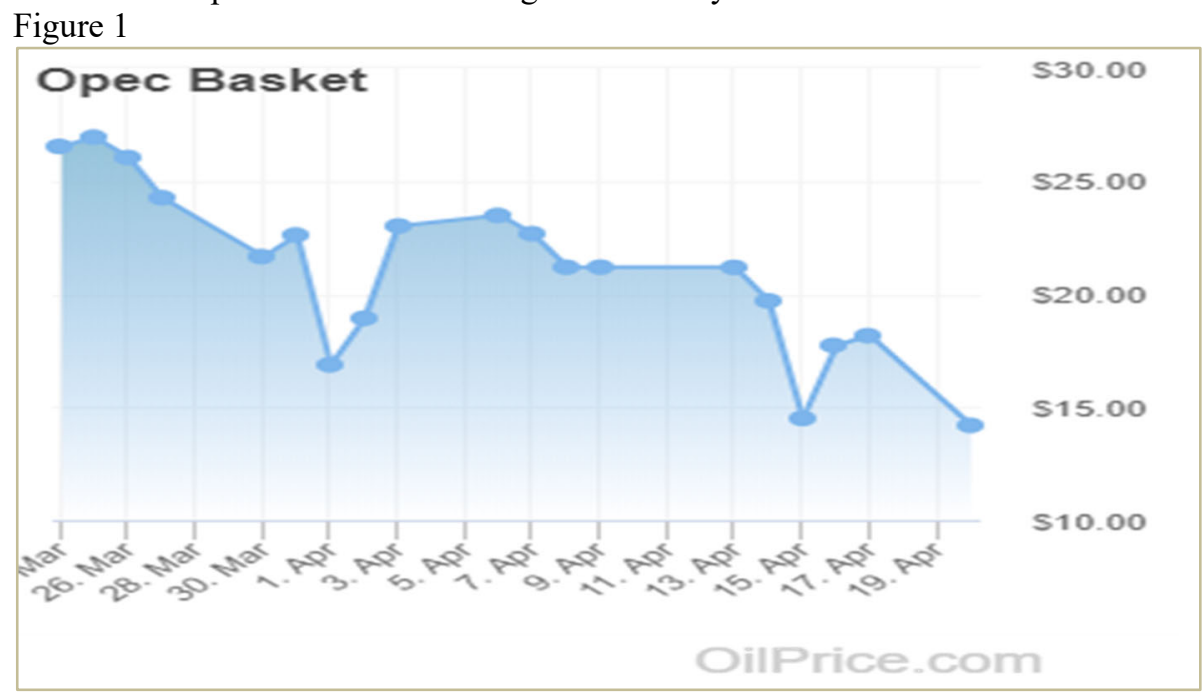

Source: Oil Price 2020

Above is a graphical representation of the volatile nature of the opec price for oil in the last one month due to the oil price war between Saudi Arabia and Russia, also due to the global pandemic which fell oil price to $\$ 14$ per barrel as of April 22nd, 2020.

\section{Oil price pre COVID - 19 and COVID - 19}

Below is the monthly price trend of oil volatility in 2020 during the occurrence of oil price collapse due to oil war 
between Saudi Arabia and Russia and the global pandemic due to Covid19.

Table 1

\begin{tabular}{ll}
\hline Month 2020 & Price (\$) \\
\hline January & 58.94 \\
February & 50.16 \\
March & 22.61 \\
April & 14.36 \\
May & 29.03 \\
June & 38.22 \\
July & 43.02 \\
August & 48.27 \\
September & 40.65 \\
October & 36.5 \\
November & 46.79 \\
December & 46.67 \\
\hline
\end{tabular}

Figure 2

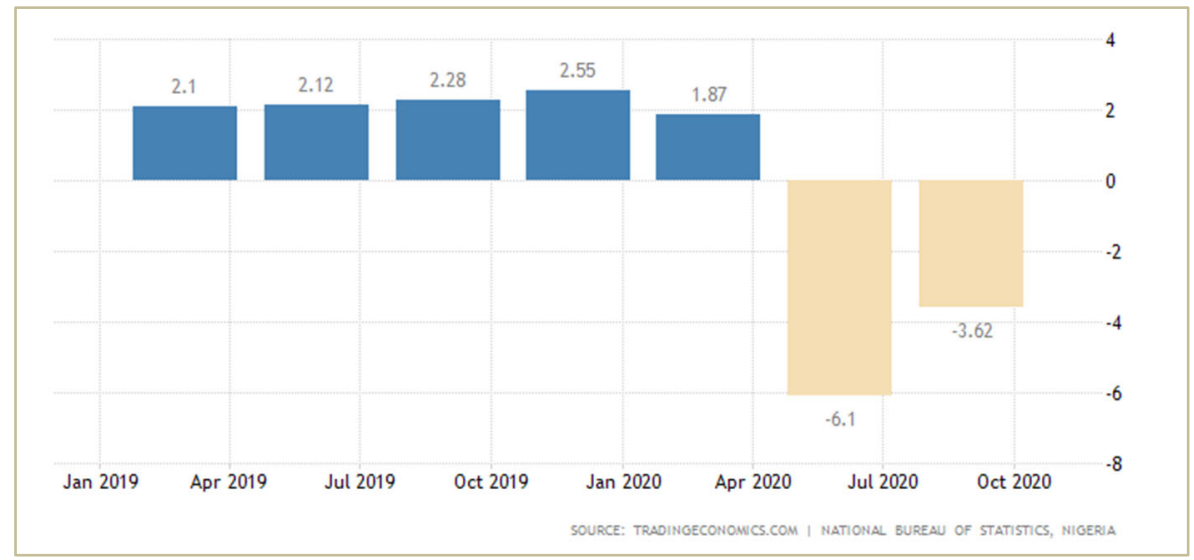

Source: Trading Economics

The above graph shows the GDP annual growth of Nigerian economy from 2019 to 2020 prior to the covid19 to the year when oil exporting Nigeria was faced with the deadly virus which affected all OPEC nations. It clearly shows the negative effects on the annual growth of the Nigerian economy's GDP which led to factors mentioned in this article.

\section{Impact of Crude Price Volatility Caused by the COVID - 19 Pandemic on Nigeria}

Nigeria is Sub Saharan Africa's largest economy and relies heavily on oil as its main source of foreign exchange earnings and government revenues.

Nigeria produces only about $2.7 \%$ of the world's oil supply (in comparison, Saudi Arabia produces $12.9 \%$, Russia produces $12.7 \%$ and the United States produces $8.6 \%$ ). The petroleum sector is important, as government revenues still heavily rely on this sector, the recent pandemic caused by corona virus has further exposed the economy of Nigeria and oil price crash put the country just like others in a state of impending recession (Financial Time, 2020). Nigeria relies on crude receipts for more than half of government revenues and virtually all its foreign exchange and the previous time oil prices plummeted, in 2015, the country sank into a recession from which it has only recently, and barely, recovered. Economists said that downturn was both exacerbated and prolonged by policy errors, including central bank resistance to what was an inevitable naira devaluation.

In 2020 Nigeria's Finance Ministry stated that Nigeria being Africa’s biggest crude exporter seeks \$7bn in emergency funds to couching the effect of oil price shook in the face of imminent recession. The Nigerian Finance Ministry has already reduced the government's projection of 2.1 million barrels a day of oil production to 1.7 million and is working to cut Nigeria's record \$35bn budget for 2020, passed in December 2019 which was based on an oil price of $\$ 57$ a barrel, by about 15\% (Financial Times, 2020), with Oil trading at an average of USD \$30. The IMF is considering Nigeria's emergency request for \$3.4bn funding and World Bank release of $\$ 82 \mathrm{~m}$ instead of the $\$ 2.5 \mathrm{bn}$ sought by the country. In the response to the Covid-19 pandemic, the Nigerian government formed an Economic sustainability committee (ESC) of a seven member team chaired by the Vice president of the country on the directive by the Nigerian President that the Committee in collaboration with domestic sectors of the Nigerian economy, work out how the country can improve its economic stimulus packages 
for citizens from what is gotten from International Monetary funds (IMF) and Word Bank. The committee is made up of Minister of Finance, Budget and Planning; Industry, Trade and Investment; Labour and Employment; Minister of State Petroleum Resources; CBN Governor; NNPC Group Director and Permanent Secretary, Cabinet Secretariat who serves as secretary of the committee (ThisDayLive, 2020).

The oil price drop has pushed the Nigerian government to finally attempt to remove the petrol subsidy, which had fixed fuel at N145 a litre and absorbed billions of dollars in spending. Economists have long advocated an end to the costly subsidy regime, and recently the head of the state-owned Nigerian National Petroleum Corporation (NNPC), acknowledged on local media that the subsidy had mainly benefited multiple car-owning elites (Financial Times, 2020). The Management of Nigeria's Nigerian National Petroleum Corporation (NNPC) has assured the Nigerian citizenry that the slump of crude oil price below $\$ 0$ per barrel would not have any reflection on the reality of the global oil mark and that of Nigeria's oil production (Premium Times, 2020). The NNPC further indicated that it was not the real crude oil price but the traders paper figure just showing the details at the close of their business for the month (Premium Times, 2020). An additional statement with regards to Shale Oil was put out by the NNPC leadership stating the US shale oil (which is West Texas Intermediate oil) does not influence Nigeria, since Nigeria trades in Brent and Bonny light which from all indications maintained an average of $\$ 20$ per barrel, in fact highlighting that Nigeria achieved the highest oil production because of the current situation with Nigeria approaching 2.45million barrels per day (Premium Times, 2020).

\section{COVID - 19 Value Chain Impact of the Global and Nigerian Petroleum Industry}

Many participants in the oil and gas industry will have experienced déjà vu as oil prices have once again crashed, this time due to the destruction of demand associated with COVID-19 and the price war between Russia and Saudi Arabia.

\section{The Petroleum Industry}

The global lockdown caused by the COVID-19 pandemic has forced a transition of the industry into a state of crisis. The Progressive weakening of global oil demand at the beginning of 2020 has been intensified by the increasing systemic oversupply induced by the Russia-OPEC market share war. Together, these two variables have driven oil prices to a 20-year low. Although some production cuts were later decided upon by OPEC, Russia and other producers, these price-support efforts have had a relatively modest impact (Rogers., Guzman., Monzon, 2020).

The economic downturn created by the COVID-19 crisis is likely to deliver a big blow to many businesses, with the oil \& gas industry currently stuck in a period of oversupply, low prices and uncertainty. Over the past 10 years, investors have considered the sector increasingly unattractive. As the conventional oil \& gas business models becomes much riskier and less financially viable, any more prolonged period of oil prices is likely to see them divert their resources elsewhere (Rogers., Guzman., Monzon, 2020).

While the global economy will eventually recover, it is unlikely to return to its pre-Covid-19 "business as usual" condition quickly (if at all). Instead, due to lower economic activity and increasing pressure to use greener energy sources, the oil \& gas industry is likely to face prolonged, significantly reduced demand. Similarly, oversupply problems whether due to burgeoning oil volumes from US shale or the battle for market share between OPPs, must also be tackled by the industry.

A "Back to Normal" scenario depends on an early, bounce-back of the global economy, combined with failure to progress the climate-change/renewables agenda. At the same time, it requires major oil producers to agree production cuts that are sufficiently rapid and deep that current oversupply is reduced. Achieving these conditions seems unlikely.

The scenario of Stagnation, in which the global economic recovery and the effects of oil demand appear to be far more likely. In this scenario, the continued implementation of renewables and low-carbon sources of energy holds back the sow demand recovery. In this case, however producers can gradually reduce oversupply in order to encourage moderate prices that ensure the feasibility of many ventures.

Undoubtedly, the worst possible scenario is "Severe injury", perhaps mixed with accelerated demand destruction induced by the transition to renewables, combined with persistent over-supply, owing to repeated failures by major producers to consent to sufficiently deep production cuts. On the positive side, any lasting decrease in demand will provide strong political and financial incentives for OPEC and other major producers to adjust output to an acceptable price level. This makes this situation less probable.

The level of injury inflicted on both individual players and the broader industry will therefore largely depend on whether, perhaps at the cost of market share, OPEC will commit to supporting prices in this way.

Given these conditions, the "New Normal" scenario is another possible outcome. In this case, after a few months the economy is bouncing back combined with a relatively slow erosion of demand due to tightening climate change policies, oil prices should be boosted. Even if OPEC and other manufacturing struggle to curb supply as much as in the past, this would be the case (Rogers., Guzman., Monzon, 2020). 
A closer examination of sub-sectors within the industry reveals the degree to which each will be affected:

- It will be increasingly difficult for International oil companies (IOCs) to expand organically, with some high-cost and stranded assets being written off. However, as smaller players struggle to survive, there will be M\&A opportunities.

- National oil companies (NOCs) will push to accelerate production with big, low-cost reserve positions, but those with higher cost structures will struggle. Lower national budgets will exacerbate debate on prioritization between oil reinvestment and social needs due to reduced oi \& gas revenues. The crisis maybe be used by some governments to stimulate support for energy transition programs.

- Due to systemic overcapacity, heterogeneous market evolution and tighter product-quality requirements, refiners will face low margins and returns for several years. Some small-scale plants would also not even be able to recover their cash costs for operating and maintenance.

- Oilfield services players face exceptionally low asset utilization because of project cancellations or deferrals and production shutdowns. In this section, serious capacity cutbacks and major employee losses are likely to continue.

\section{- Crude Oil Marketing and Trade}

US oil prices turned negative for the first time on record on Monday 20/04/2020 after oil producers ran out of space to store the oversupply of crude left by the coronavirus crisis, triggering an historic market collapse which left oil traders reeling.

The price of US crude oil crashed from $\$ 18$ a barrel to $-\$ 38$ in a matter of hours, as rising stockpiles of crude threatened to overwhelm storage facilities and force oil producers to pay buyers to take the barrels they could not store. The market crash underlined the impact of the coronavirus outbreak on oil demand as the global economy slumps. It should also serve as a warning for the Organisation of Petroleum Exporting Countries (OPEC) of how bad the demand problem has gotten.

Nigeria's crude oil is benchmarked against the Brent crude. At present, the price of a barrel of Brent crude is \$25. Although traders in the market said Nigeria's Bonny Light was sold for between $\$ 13$ and $\$ 15$ recently, the price is not yet in negative territory. It is expected that the global economy will rebound gradually once coronavirus-induced lockdowns are lifted and activities resume.

The price of US crude oil crashed from $\$ 18$ a barrel to $-\$ 38$ in a matter of hours, as rising stockpiles of crude threatened to overwhelm storage facilities and force oil producers to pay buyers to take the barrels they could not store. The market crash underlined the impact of the coronavirus outbreak on oil demand as the global economy slumps. It should also serve as a warning for the Organisation of Petroleum Exporting Countries (OPEC) of how bad the demand problem has gotten. It is critical that OPEC \& Non-OPEC producers can come to some agreement to stabilise the price (BreakBulk, 2020).

In response to strained demand, some oil producing countries like Saudi Arabia, Iraq and Nigeria have opted to sell crude oil at discounted rates and several oil companies are scaling down on their exploration, production, and new projects budget. Nigeria's crude oil is benchmarked against the Brent crude. At present, the price of a barrel of Brent crude is $\$ 25$. Although traders in the market said Nigeria's Bonny Light was sold for between $\$ 13$ and $\$ 15$ recently, the price is not yet in negative territory. It is expected that the global economy will rebound gradually once coronavirus-induced lockdowns are lifted and activities resume. (BreakBulk, 2020).

\section{- Upstream \& Midstream}

Oil and gas operational activities are generally considered essential activities by the Nigerian government and have been mostly exempt from the lockdown measures. However, continued operations will likely become increasingly difficult due to workforce shortages as employees are infected by the coronavirus and the practical difficulties in many cases of social distancing. Every organization within the sector will be running skeleton crews to continue operations, with disruptions expected for the maintenance, inspection, repair and replacement of equipment and drilling activities.

A where contractual performance is impossible, difficult or onerous to perform as a result of exceptional events o s the situation deteriorates, many industry participants are reaching for the force majeure (FM) provisions in their key contracts to excuse failure to perform or to exit. Whilst these are typically designed to cover a situation utside either party's control (for example a global pandemic), relying on a FM clause is very heavily dependent on the factual circumstances and the drafting of the specific clause. The choice of the contract's governing law will also influence the availability of FM and similar reliefs including possible change of law relief.

As instability and uncertainty increase, so will the number and types of disputes due to businesses becoming unable (or unwilling) to perform existing contractual obligations. 


\section{- Downstream}

Globally refining has often offset oil price declines in the crude markets, with margins and volumes typically growing as crude prices have fallen. But this time is different. Today, while crude oil prices are falling due to oversupply, there is also a rapid decline in demand (both domestically and internationally). This plummeting demand comes in the wake of the response to COVID-19, which has shuttered large parts of the economy, including a slowdown in all kinds of business and personal travel, especially commuting by car. Some analysts estimate that gasoline demand could be slashed by $50 \%$ during the months most impacted by the COVID-19 outbreak. This depleted demand is already creating inventory problems in both the distribution network and at the refineries.

This has led to dramatic drops in the crack spread (pricing difference between a barrel of crude oil and the petroleum products refined from it), with many markets experiencing negative crack spreads. The EIA Daily prices report for April 13, 2020, shows the WTI/USGC 3:2:1 crack spread at -0.084 .

As spreads invert and inventories begin to top out across the fuel distribution and retail network, refinery shut-ins will be required, with output necessarily shunted to the export markets, this may pose a problem for Nigeria in the long run which relies heavily on imported petroleum products to supply into the domestic market. The NNPC for now has assured the nation of adequate supply of PMS in the short run.

\section{- Issue of oil storage}

The oil and gas industry have been hit hard over the last couple of months by twin crises, a conflict between Saudi Arabia and Russia over production allowances and Covid19. The COVID-19 virus had a huge impact on the global oil market. The virus and the economic crisis it evoked results in a large decline of the oil demand.

\section{Further Impact Assessment}

\section{- Assessment}

Generally, the prices for African oil have fallen by more than half during the last past month due to the outbreak of the new coronavirus (COVID-19) has added a major layer of uncertainty to the oil market outlook at the start of the forecast period covered by this report. In 2020, global oil demand is expected to contract for the first time since the global recession of 2009. The situation remains very fluid, however, making it extremely difficult to assess the full impact of the virus (IEA,2020). The volatile nature of oil prices during the COVID-19 pandemic has brought a lot of confusion and readjustments to the policy and budgets of majority of its producers especially in developing nations like Nigeria.

Figure 3

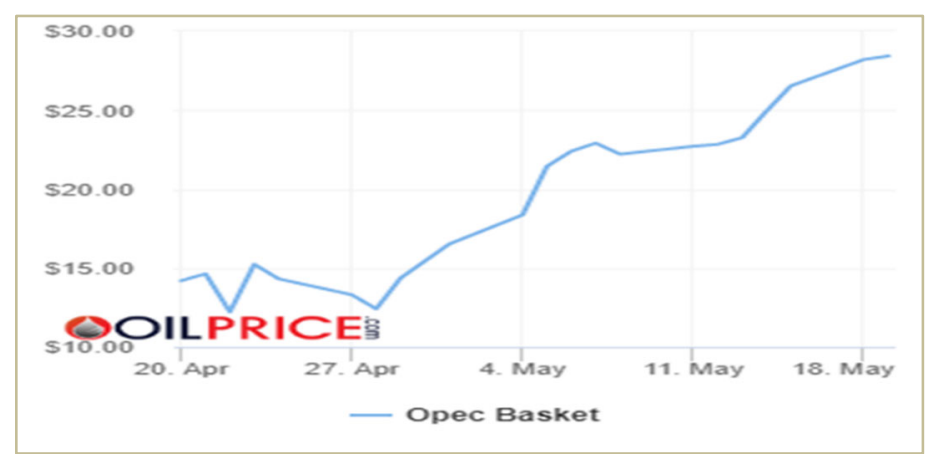

Source: Oilprices.com 2020

In the chart it shows the volatile nature of the oil prices during the corona pandemic in the space of 2 months and how it has shown that the product is an unstable commodity during an economy issue. Nigeria has had to sit up and come up with different policies to cushion the price shock but most importantly one of the policies advised by key members of the economic forum was reduction of pump price.

The IEA stated that the world had not yet experienced peak oil demand and this would happen sooner or later as oil consumption would return to the pre-crisis levels or even far above that. He also stated that in the absence of a strong government policies, a sustained economic recovery and ow prices are likely to take global oil demand back to where it was and beyond.

IEA's assessment of oil demand trends for after the COVID-19 pandemic and recession could sound reassuring to major oil-producing nations that depend on oil revenues for their budgets, as well as to oil majors, some of which have expressed uncertainty whether oil demand will ever return to the 2019 levels (IEA, 2020). Top Executives of major oil corporations have recently expressed views that it's not guaranteed that global oil demand will return to its 'normal' pre-virus levels of around 100 million barrels per day (bpd). The pandemic adds not only a layer of uncertainty in the oil industry in the short term, but it also creates another challenge for the coming years, BP's Management stated to the Financial Times in an interview published earlier this month 'It's 
not going to make oil more in demand. It's gotten more likely oil will be less in demand' (IEA, 2020).

\section{- Effects on International, Regional and National}

The coronavirus pandemic has exposed the structural weaknesses in the economic paradigm of African countries as exporters of primary goods and importers of finished products, However, with innovative leadership and a belief in the continent's enterprising and dynamic young people, the pandemic can serve as an opportunity to turn the wheels of African economies back on track (Mahama.,2020).

\section{Nigeria}

Before the advent of the pandemic Nigerian crude oil production climb to the highest level in ten years (hitting about 2.4 million per day, before it went down). The National Energy Security Revenue flow has been greatly impacted by the fall in crude oil prices by about $65 \%$. This affected NNPC's liquidity position and the anticipated remittances to the Federation Account of about N1.27 trillion between April and December 2020 (Premium Times, 2020).

The crude oil price movement from 2015 was about $\$ 30$ per barrel till about early 2016, until the crash, which was unprecedented, it has never happened in the history of oil trading to have such a sharp collapse within so short a period, from excess of $\$ 60$ per barrel in February 2020, to less than $\$ 13$ in April. What that means in terms of government revenue is declining inflow. The 2020 Budget was initially premised on $\$ 57$ to the barrel. By March, it became clear the benchmark was not sustainable (Premium Times, 2020).

The budget was rebased to $\$ 30$ per barrel. Government is still talking to the National Assembly. There is a potential of rebasing it further to $\$ 25$ to the barrel. However, policy administrators were comfortable to assume the year average of $\$ 30$ (Premium Times, 2020). This will mean several changes to realities, businesses must readjust, and costs must be reviewed, expectations must be cut down to the basics, to survive through this crisis (Interestingly, as prices were going down, consumption also went down, obviously because of the lockdowns in many locations).

The other issue that is of serious concern to the NNPC is the cost of production per barrel. If the cost is not brought down significantly, there will not be any tax revenues, and therefore the investment would become worthless. The result will be that expectations will not be met, and petroleum production business in Nigeria will become something nobody would want to do.

In Saudi Arabia, one can produce oil at less than USD\$5. Saudi's reservoirs are quite different from Nigeria's. One can lay the oil pipelines on the surface and nobody will tamper with it. The environment in Saudi is different from the Niger Delta.

Hence with Nigeria's current cost of production averaging between $\$ 15$ - \$25 per barrel, when crude oil prices go to as low as $\$ 12$ or $\$ 13$ to the barrel, it means, technically, the operators are subsidizing crude oil production. NNPC must engage to bring down the high cost by re-negotiating contracts, cutting down on contracting life cycle; selecting the right projects; engaging the right institutions to bring down the cost, with an ultimate production cost outlook to a maximum of $\$ 10$ per barrel.

\section{- Crude Production Impact}

Nigeria's decision to participate in the OPEC+ output cut regime has enforced a commitment to bring down our o production to 1.412 million barrels per day (BPD) between May and June and 1.495 million BPD between July and December 2020. Thereafter 2021, in January until April 2022, we will be producing 1.579 million BPD. Since January 2020, crude oil production has remained at 1.81 million barrels per day, and condensate production averaged 250,000 barrels per day and 280,000 BPD.

According to NNPC the OPEC+ production cut deal was necessary to re-balance the oil market and move Brent prices $\$ 42$ to $\$ 45$ a barrel by the end of the year. Over a 10 day period the country has been cutting more than the required under the OPEC + . Nigeria was pumping 1.41 milion barrels a day in line with the OPEC + target for May and June. The Nigeran government has cut supply as much as 45,000 barrels in the third quarter and over produced by only 100,000 barrels in May (Cranny., M, Smith, G and Ratcliffe., 2020). Nigeria was therefore eager to comply with the Organization of the Petroleum Exporting Countries + (OPEC+) production cut agreement to address these severe imbalances, which he said was in the best interest of the global economy. With increasing conformity and participation from oil producers in these supply cuts, NNPC predicted that the cuts will not need to extend past August (Croft, 2020).

\section{Fiscal crisis, Increase in debt and Effect on Banking}

Based on the situation the global oil exporters found themselves, this case study looks at the current trend in OPEC nations and not just Nigeria.

The study concludes that the Covid19 pandemic was disastrous to these countries and put them at a more receiving end. These effects incudes: Recession, National and International Travels bans, Effect on Banking 
Activities, Effect on the Prices of Food Items, Issue of oil storage, fiscal crisis, Increase in Debt risk, Effect on oil export and trade. Due to the global lock down and widespread of the covid19, business was hindered both locally and internationally. This then created a crisis for countries who did not have excess monetary reserve to handle the shock effect of the pandemic.

Small and medium business and a couple of large companies went burst while few were at the verge of liquidation. Hence, an initiative was brought up by the government to provide palliatives to the 36 states across Nigeria and provide loans for businesses which left the country in further crisis.

\section{- Impact National and International Travel bans}

The recent COVID-19 crisis has led to national quarantines and global travel bans, bringing international travel to a standstill. These measures are expected to have a long lasting and destructive effect on international tourism. The travel restrictions affect hotels, camping sites or other types of accommodation, but also restaurants, museums, and other activities frequented by local as well as international tourists alike (Europe data portal, 2020). Due to the restrictions and ban to National and International travels it slowed and relatively brought oil businesses in Nigeria to a halt and responsively led to an increase in global prices of travel and trade.

Figure 4

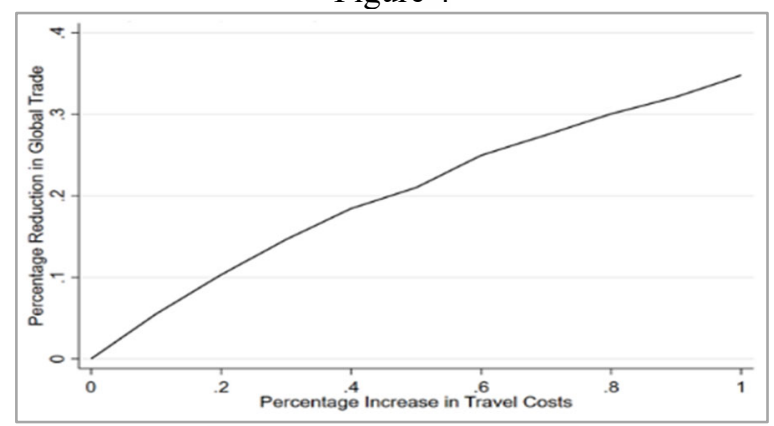

Source: Euro data portal

\section{- Effect on Banking Activities}

COVID-19 is an economic shock analogous to the global financial crisis. The COVID-19 pandemic has brought the world into exceptionally difficult and largely uncharted waters. Banks are feeling the strains alongside their clients, their employees, and the societies they serve.

\section{- $\quad$ Effect on the Prices of Food Items}

The pandemic has greatly shrunk dramatically the economic activities of nations and with it its food supply value chain. The tale of Nigeria has been no different. The country has instituted a range of measures to try to curb the pandemic. These have included waves of lockdowns in major cities, border closures and people's movement being restricted (Adegboye, 2020). These measures have affected all sectors of the economy. But food supply has taken the most severe hit and food prices had risen dramatically between February and June 2020. Some key reasons to this include; complexities of loan repayments, limited farm inputs, poor access to loans, hoarding by middlemen, greed of making abnormal profit by the farmers, role of conflict etc The impact is already being felt in the form of rising food prices. As of April 2020, food inflation rose to 15\% compared to 14.7\% in December 2019 (Pwc, 2020).

Figure 5

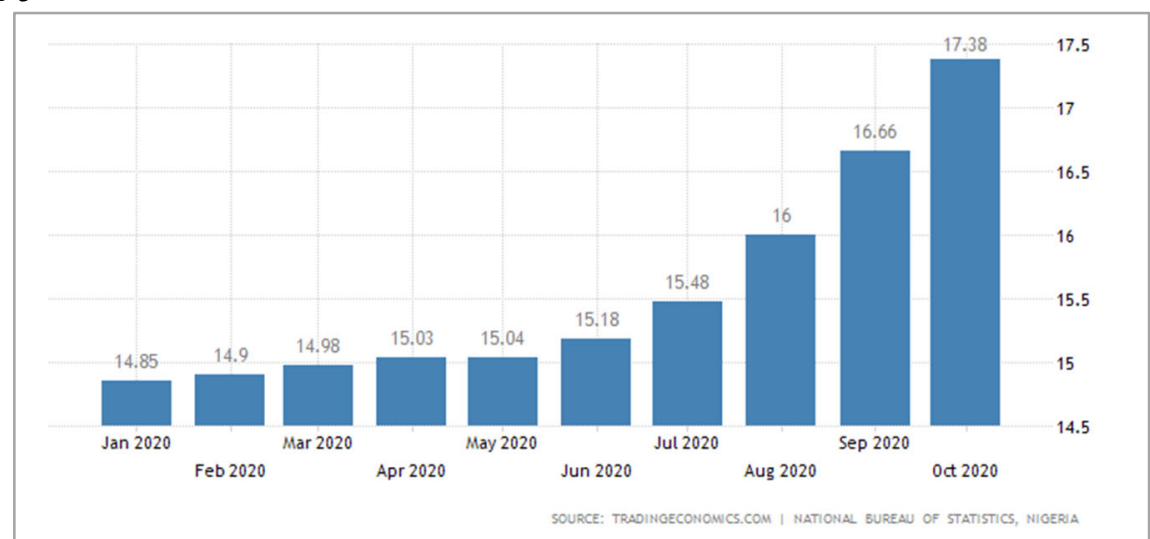

Source: Trading Economics - Inflation of Food prices

The graph above shows the sharp rise in inflation of prices of food prior covid19 till current date. 


\section{Recession Outlook}

The instant and immense shock of the coronavirus pandemic and shutdown measures to contain it have plunged the global economy into a severe contraction. According to World Bank forecasts, the global economy will shrink by $5.2 \%$ this year 2020 . That would signify the deepest recession since the Second World War, with the largest fraction of economies experiencing declines in per capita output since 1870, (World Bank Global Economic Prospects, 2020).

Economic activities among advanced economies were anticipated to shrink 7\% in 2020 as domestic demand and supply, trade, and finance have been severely disrupted. Emerging market and developing economies (EMDEs) are expected to shrink by $2.5 \%$ this year, their first contraction as a group in at least sixty years. Per capita incomes are expected to decline by $3.6 \%$, which will tip millions of people into extreme poverty this year (World Bank Global Economic Prospects, 2020).

\section{Recommendation \\ Mitigation Options to bail out the Petroleum Sector during the COVID 19 Crisis Government support}

The emergence of COVID-19 and its increasing incidence in Nigeria has called for drastic review and changes in the earlier revenue expectations and fiscal projections. Compared to events that led to recession in 2016, the current state of the global economy poses more difficulties ahead as the oil price is currently below US\$30 with projections that it will dip further going by the price war among key players in the industry (Global thinkers, 2020). Unfortunately, the nation has grossly underachieved in setting aside enough buffers for rainy days such as it faces in the coming days. In addressing these daunting economic challenges, the current considerations to revise the budget downward is inevitable. However, certain considerations that are expected in the review must not be left out. The assumptions and benchmarks must be based on realizable thresholds and estimates to ensure optimum budget performance, especially on the non-oil revenue components (Madueke et al, 2020).

The decision to cut the retail price of gasoline under a price modulation arrangement is a welcome development. The cut is expected to curb rising inflation, especially food price inflation which will mainly benefit the poor. However, rather than the price capping regime introduced, by which it is expected of the Petroleum Products Price Regulation Agency (PPPRA) to constantly issues monthly guide on appropriate pricing regime. It is expected that the government will use this opportunity to completely deregulate the petroleum industry in line with existing suggestions and reports. If the global economy becomes healthier and crude oil prices increases, the government might return to the under-recovery of the oil price shortfall by the Nigerian National Petroleum Corporation (NNPC). A policy that annually costs the government huge revenue and recurring losses to the NNPC. Basically, the Nigerian government essentially must lead economic diversification drive. It is one practicable way to saddle through the current economic uncertainties and instabilities

The COVID-19 pandemic is shattering long-held assumptions about the global economic and political order, with a clear shift towards direct government involvement in national economies and an increased risk of nationalization worldwide (Mckenzie, 2020). The Government will have to bail out the sector via:

\section{- Taxation}

Most governments have announced new taxation measures to support businesses including deferral of payments, expedited customs clearance and suspension of interest on tax payments. The Nigerian Government through the Ministry of Finance, FIRS, DPR and NNPC have key roles to play

\section{- Debt Management}

In response to COVID-19, governments have announced various measures to support companies' debt arrangements including deferred payments, guaranteed credit facilities, and government-backed loans. Foreign Investment Oversight Consolidation through the acquisition of distressed assets is a textbook response to slumps in the industry; and some did it successfully following the 2014/15 price fall. Given the speed, scale and volatility of the crisis, it is premature to gauge the buy side interest. In many countries, governments have tightened their oversight of foreign investment rules to protect vulnerable domestic companies laid low by the crisis.

Businesses and investors must carefully consider foreign investment review risks at this overly sensitive and volatile time. Taking the time to understand the rules, which are changing day after day, and identify a regulatory strategy, including appropriate messaging and communication with the relevant governmental authorities, and the consequential impact on deal documentation. DPR, NNPC have a key role to play here.

\section{- $\quad$ Financial Incentives \& Stimulus Packages}

Redetermination of borrowing base facilities to shelter upstream producers from the risk of payment default. Ministry of Finance, DPR and NNPC are the key role parties. While it is simply too early to tell the energy outlook for the future because of the Covid-19 influence, the world will move beyond this and the business case for 
streamlining operations and investing in resilience planning will be reinforced and widely accepted.

\section{On Operations}

Operators will also need to consider:

- third-party contractors who work on-site and the alignment of COVID-19 policies; and

- the prospect of sealing off wells because of the reduced number of personnel on drilling rigs falling below the level required by health and safety regulations and the reasonable and prudent operator standard.

\section{Counterparty credit}

Focus will now be on credit risk associated with counterparties as financial stress flows through the sector. This suggests that an extension of payment terms and innovative financing structures is likely, which will hopefully leverage stronger balance sheets and help sustain weak counterparties while mitigating creditors' risk (e.g. through share and/or asset security), may again become prominent (Mckenzie, 2020).

\section{Business Models to be Adopted by Nigeria}

Some hydrocarbon business models are projected to co-exist in the future, with varying chance of success depending largely on industry stakeholder's its ability to transform after the crisis:

1. Diversified energy holdings: By rapidly shifting away from their increasingly unattractive conventional business models, the IOCs will respond to the twin challenges of low prices and decarbonization, becoming energy holding companies with more diverse interest. They already foresee that oil demand will peak, and they expand organically beyond hydrocarbons more and more after covid-19. In a world that is moving towards cleaner energy sources, they will turn their global oil \& gas operations into genuinely diversified energy holdings that are resilient. IOCs will also aim to improve their value chains for natural and their integration into petrochemicals.

2. Regional "mini-majors": To turn their businesses into regionally tailored, integrated and diversified modes, most regional players will exploit their geopolitical, cultural, logistical and commercial advantages. They can become "mini-IOCs" that are diversified or maybe concentrate more strongly on oil \& gas.

3. Special-purpose vehicles (SPVs):

In order to provide greater financial stability within their portfolio consolidation strategies, oil \& gas companies will gradually build SPVS. While there is no single business model that will allow future success, the path towards the "future oil company" needs businesses to implement transition strategies now that will prepare them for an unpredictable and evolving environment.

They need to think carefully about their long-term survival paths, identify growth options, and take deliberate, meaningful and strategic actions to protect themselves against what is now the very real risk of early obsolescence.

In their conventional market segments, businesses need to boost capital returns while pursing opportunities for potential growth in renewables through a mix of acquisitions and new ventures pilots. If they are to thrive and establish long term sustainable competitive positions, they will need to undergo deep transformation of their cultures, skills and capabilities. The challenges are immense and not all the oil companies of today are likely to succeed.

In this transition, they could not only divest high cost upstream projects, including shale or tar sands, focusing instead on low-cost assets, but also curb high-risk exploration. They should cancel or carefully review new construction of refining projects or plant upgrades, considering the extremely limited time window to secure returns from such investments. They will need to rebalance their businesses through stronger positions in the natural-gas value chain and petrochemicals, they would need to rebalance their companies.

\section{Conclusion}

Nigeria as a country which is over dependant on oil, needs to reconsider the policies in place to ensure the country has a favourable balance post COVID - 19. International and global economies have adopted a series of inward and positive moves to couching the effects of oil price volatility and economic imbalance due to covid19 effects.

One thing that has been established is that it's not possible to underestimate its impact on unemployment, additional job loss, increased poverty, hunger, combined with a major drop in oil prices, Therefore, this study concludes that drastic economic policy steps need to be established and formulated to aid struggling businesses and SME's in this time of difficulties, palliatives, soft social loans should also be made readily available to the most impacted.

The scope and gravity of the global economic crisis in Nigeria, caused by the fall in oil price and the COVID19 pandemic, is a clear signal that growth and development reforms are needed in Nigeria.

The government will need to come up with a broad socioeconomic plan to implement measures to support households in terms of cash payments and food assistance, unemployment assistance, Tax delays while also 
supporting businesses that are distressed in different sectors, improving health care system.

\section{Reference}

Adegboye, F.,B 2020 Food prices in Nigeria have shot through the roof. But is the pandemic to blame?

Anderson, R.M., Heesterbeek, H., Klinkenberg, D. and Hollingsworth, T.D., 2020. How will country-based mitigation measures influence the course of the COVID-19 epidemic? The Lancet, 395(10228), pp.931-934.

Breaking Bulk, 2020 OIL PRICES AT AN ALL-TIME LOW

Chauhan, S., 2020. Comprehensive review of coronavirus disease 2019 (COVID-19). Biomedical Journal.

Cranny, M., Grant, S., Ratcliffe, V, 2020 Nigeria Vows Full Compliance With OPEC+ Oil Cuts by Mid July

Croft., H, 2020 Virtual fireside chat with Mele Kyari, group managing director of the Nigerian National Petroleum Corporation: The Nigerian view on the global oil market

IEA, 2020 The global oil industry is experiencing a shock like no other in its history

IEA, 2020 OIL2020

IEA, World Energy Outlook 2020

Financial Times, 2020 Oil prices hit lowest level in 17 years as demand plunges

Financial Times, 2020 What negative US oil prices mean for the industry

Financial Times, 2020 Nigeria in 'crisis' as oil receipts plummet

Guardian, 2020 Oil prices dip below zero as producers forced to pay to dispose of excess

Global Thinker, 2020 The implication of COVID-19 pandemic on the Nigerian Economy

Madueke, O., Iheonu, A. and Emmanuel, O.E., 2020 Post Covid-19 Pandemic Nigeria: Implications for Good Governance and Development.

Mahama., D, J., 2020 Coronavirus has exposed Africa's economic paradigm

Mckenzie., B, 2020 The Impact of COVID-19 on the Oil \& Gas Industry

Oil Price, 2020 Saudi Arabia Claims the U.S. Was Not Their Target In The Oil War

OECD, 2020 OECD Policy Responses to Coronavirus (COVID-19) COVID-19 and Africa: Socio economic implications and policy responses

Premium Times, 2020 Why U.S. \$0 oil should not bother Nigeria

Premium Times, 2020 Covid-19: Look to Agriculture to boost Nigerian economy, Shuaib tells Buhari, Investors by Idowu Bankole

Premium Times, 2020 Nigeria does not need PIB to deregulate oil sector

PWC, 2020 Responding to the impact of Covid-19 on food security and agriculture in Nigeria

Rogers, S., Guzman, R., and Monzon, D., 2020 Petroleum: Surviving in the post-COVID-19 era

The Guardian, 2020 Buhari receives Economic Sustainability Committee Report

ThisDayLive, 2020 Economic Sustainability Plan Ready Soon, as Osinbajo Meets IMF, World Bank Representatives

World Health Organization, 2020. Coronavirus disease (COVID-19).

World Oil, 2020 Russia paid a heavy price to end the oil price war

World Bank, 2020 COVID-19 to Plunge Global Economy into Worst Recession since World War II 